\title{
Erytrocyttransfusjon ved Ullevål sykehus - indikasjoner, forbruk og blodtypeimmunisering
}

Engelsk oversettelse på www.tidsskriftet.no

\begin{abstract}
Sammendrag
Bakgrunn. Kunnskapen om klinisk transfusjonspraksis bør bedres for å sikre optimal effekt av behandlingen, unngå ressurssløsing og sikre trygg blodforsyning.
\end{abstract}

Materiale og metode. Alle som ble transfundert med erytrocyttkonsentrat ved Ullevål universitetssykehus $i$ to 14-dagers driftsperioder i 2003 ble inkludert. Diagnoser, hemoglobinverdier og inngrepskoder ble registrert fra journaler der det var gitt tillatelse til innsyn. Blodprøve ble innhentet fra samtykkende overlevende til undersøkelse på blodtypeimmunisering.

Resultater. 348 pasienter ble inkludert. Medianalder var 62,8 år. De fikk 1162 konsentrater fordelt på 471 transfusjonsepisoder, hvorav 373 (79\%) omfattet ett eller to konsentrater. Per 1.2. 2009 var 181 pasienter (52\%) registrert som døde. Journalinnsyn ble mulig hos 218. Kreftsykdom var hoveddiagnose hos 76 (35\%), skader hos 36 (17\%) og kardiovaskulær sykdom hos 34 pasienter (16\%). Hos 89 (41\%) pasienter ble transfusjonen gitt ved et operativt inngrep i registreringsperioden. Notat om transfusjonen manglet i 46 av journalene ( $21 \%$ ). Transfusjon ble gitt ved hemoglobinkonsentrasjon på $\geq 8 \mathrm{~g} / 100 \mathrm{ml}$ hos 52 av pasientene med angitt hemoglobinkonsentrasjon ( $43 \%$ ). Hos én av 38 overlevende (3\%) ble det påvist blodtypeimmunisering.

Fortolkning. Erytrocyttransfusjon blir oftest gitt til eldre med kroniske lidelser og usikker langtidsprognose. Den kliniske dokumentasjonen er ikke sjelden mangelfull. Det er trolig rom for forbruksreduksjon hvis indikasjonene blir mer basert på etablert kunnskap og veldefinerte transfusjonsprotokoller. Blodtypeimmunisering er ingen hyppig komplikasjon.

\section{Hans Erik Heier}

h.e.heier@medisin.uio.no

Institutt for klinisk medisin

Universitetet i Oslo

og

Avdeling for immunologi og transfusjonsmedisin Klinikk for diagnostikk og intervensjon

Oslo universitetssykehus

\section{Ivo Nentwich}

Liv Jorunn Garvik

Berit Gran

Avdeling for immunologi og transfusjonsmedisin Klinikk for diagnostikk og intervensjon

Oslo universitetssykehus

Transfusjon skal bare anvendes når det er sannsynlig at pasienten vil profittere på tiltaket og det ikke er for stor risiko for bivirkninger $(1,2)$. Tilgjengelige data viser store forskjeller i forbruksmønster for erytrocyttransfusjon mellom sammenliknbare land og sykehus (3-7). Flere forfattere mener at dette skyldes manglende kunnskap om eksisterende retningslinjer og kunnskapsbasert transfusjonspraksis $(8,9)$. Dette gjør det interessant å undersøke hvordan erytrocyttransfusjon praktiseres ved et stort norsk sykehus.

Studier fra flere vestlige land har vist at det er en overvekt av eldre med kreft eller annen kronisk, progredierende sykdom blant de transfunderte (10-12). Tilsvarende undersøkelser er ikke utført her i landet. Økende andel eldre og kronisk syke i befolkningen vil kunne føre til økt behov for erytrocyttkonsentrater. Transfusjonstjenesten i Norge vil i så fall kunne få problemer med å skaffe tilstrekkelig med blod til transfusjon (13). Kunnskap om transfusjonspraksis vil kunne bidra til å vurdere om vi kan og bør redusere vårt forbruk av erytrocyttkonsentrater.

Vi har ønsket å bidra til å belyse hvordan erytrocyttransfusjon anvendes i Norge. Vi har derfor gjennomført en kohortoppfølgingsstudie av mottakere av erytrocyttkonsentrater ved Ullevål universitetssykehus (nå del av Oslo universitetssykehus). Sykehuset hadde en meget bred virksomhet - med så vel akuttfunksjoner som behandling av pasienter med kreft og andre kroniske sykdommer.

\section{Materiale og metode}

Studiedesign og tillatelser

Alle pasienter som ble transfundert ved Ullevål universitetssykehus $\mathrm{i}$ periodene 1.-14. mai og 1.-14. september 2003 ble inkludert. De to registreringsperiodene omfattet 7,6\% av året 2003 og ble valgt fordi man antok at de var representative for ordinær drift ved sykehuset. Studiedesignen er vist i figur 1 . Studien ble godkjent av regional etisk komité for Helse Øst i 2003.

Antall transfusjonsepisoder og transfunderte enheter erytrocyttkonsentrat $i$ de to periodene ble registrert for hele studiekohorten i 2003 og behandlet anonymisert. Forekomst av irregulære blodtypeantistoffer før transfusjon ble lagret avidentifisert.

Helsedirektoratet ga i 2006 etter søknad tillatelse til innsyn $\mathrm{i}$ journalen til pasienter som var registrert som døde i folkeregisteret og som var over 15 år ved transfusjonstidspunktet.

Per 15.2. 2008 ble folkeregisteret konsultert angående pasienter som var registrert som døde. Ultimo februar 2008 ble brev sendt til alle antatt overlevende som var over 15 år ved transfusjonstidspunktet der personalia og adresse var kjent. Brevet inneholdt en anmodning om tillatelse til innsyn i journalen, og mottakeren ble bedt om å avgi ny blodprøve til undersøkelse på irregulære blodtypeantistoffer. Det ble ikke sendt purrebrev. Folkeregisteret ble også konsultert for døde da alle data var innsamlet primo februar 2009.

Undersøkelse på forekomst av irregulære blodtypeantistoffer hos pasienter som avga ny blodprøve i 2008 ble utført som pretransfusjonsprøve med samme metodikk som ble brukt i 2003. Resultatene ble lagret avidentifisert.

\section{Gjennomsyn av journaler}

Alle journaler der innsynstillatelse var gitt, ble sett gjennom av én av forfatterne (IN). All datainnsamling var avsluttet primo mars

\section{Hovedbudskap}

- Den typiske mottaker av erytrocyttransfusjon er en eldre pasient med kronisk sykdom, ofte kreft, og usikker langtidsprognose

- Journaldokumentasjonen av transfusjonsbehovet er ikke sjelden mangelfull

- Det er trolig rom for en mer restriktiv transfusjonspraksis, slik at utnyttelsen av begrensede ressurser kan optimaliseres

- Erytrocyttransfusjon fører ikke ofte til blodtypeimmunisering 


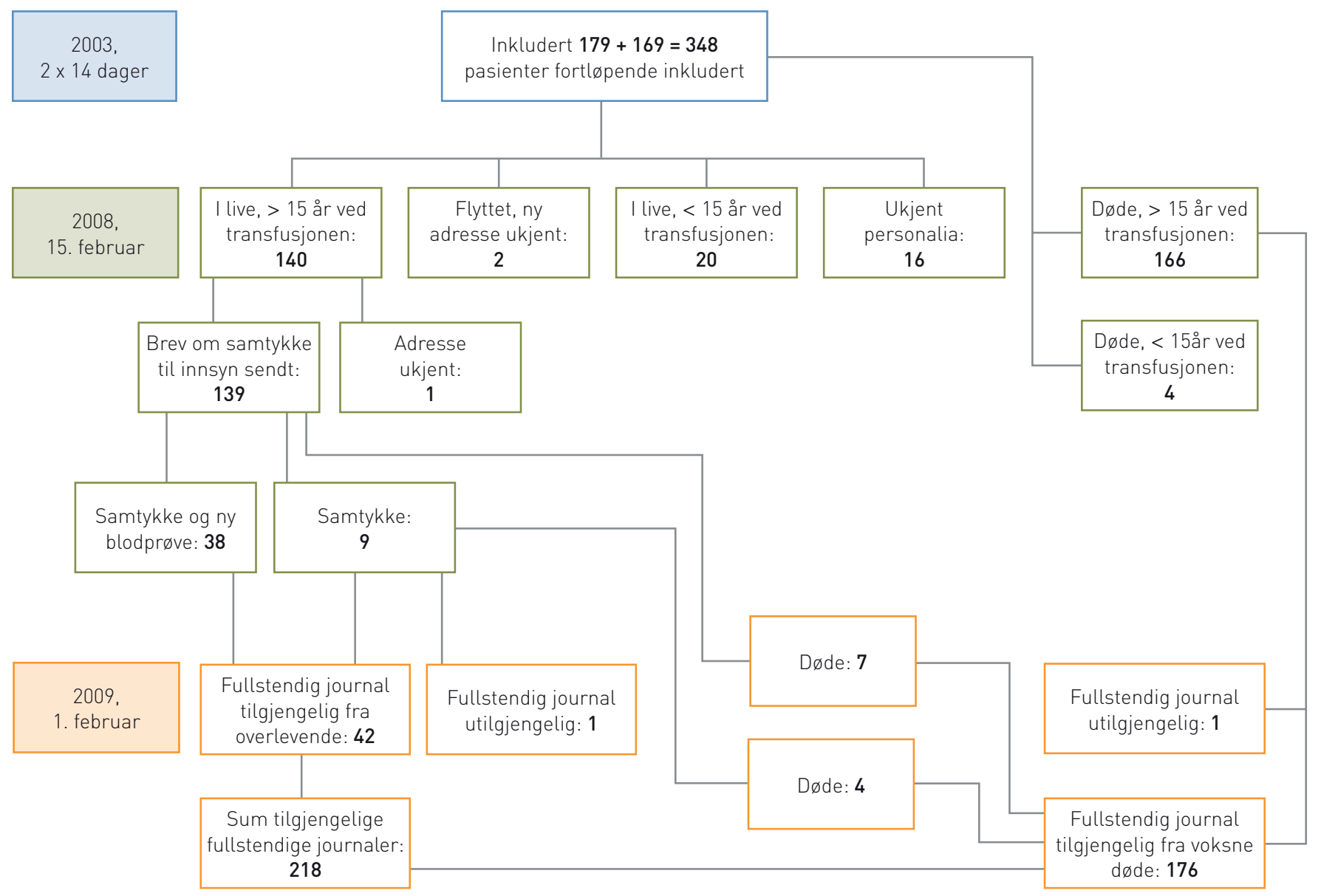

Figur 1 Flytskjema for studiedesign og -forløp

2009. ICD-10-diagnose, kirurgiske inngrep, transfusjoner og journalnotater om transfusjon samt forekomst av irregulære blodtypeantistoffer før transfusjon og ved ny undersøkelse i 2008 ble registrert og lagret avidentifisert.

\section{Statistikk}

Mann-Whitneys U-test ble brukt for å teste forskjell mellom medianer i to grupper med ikke-normal fordeling. For testing av proporsjoner ble det hhv. anvendt khikvadrattest og khikvadrattest for trend.

\section{Resultater}

\section{Pasientkarakteristika} ved transfusjonstidspunktet

I de to registreringsperiodene ble det gitt erytrocyttransfusjon til henholdsvis $179 \mathrm{og}$ 169 pasienter, til sammen 348. Det var 178 kvinner og 170 menn. Aldersfordelingen er vist i figur 2 - median alder var 62,8 år, spredning 0-99 år. 188 pasienter (54\%) var 60 år eller eldre, $i$ aldersgruppen $0-10$ år var $\operatorname{det} 38(11 \%)$.

\section{Overlevelse og tillatelse til journalinnsyn}

Figur 1 er en oversikt over studiens og pasientpopulasjonens utvikling. Per 15.2. 2008 var $170(49 \%)$ registrert $\mathrm{i}$ folkeregisteret som døde, av dem 97 menn og fire som var under 15 år ved transfusjonstidspunktet. For
16 pasienter kunne tilstrekkelige personalia til søk i folkeregisteret ikke fremskaffes, og to hadde flyttet til utlandet. Til 20 overlevende som var under 15 år ved transfusjonstidspunktet, ble det ikke sendt brev. Til én pasient over 15 år ble det ved en feil ikke sendt brev. Det ble dermed sendt brev til 139 antatt overlevende. Det kom svar fra 47, som alle ga tillatelse til journalinnsyn.

Ved søk i folkeregisteret primo mars 2009 var ytterligere 11 pasienter registrert som døde. Fire av disse hadde gitt tillatelse til journalinnsyn. Med dette var 181 pasienter (52\%) registrert som døde. Fullstendig journal var tilgjengelig for 218 av de $220 \mathrm{der}$ tillatelse til innsyn forelå. Ubearbeidet overlevelse (crude survival) inntil 5 3/4 år, basert på faktisk registrerte døde, er vist i figur 3 .

\section{Diagnoser og journalnotater om transfusjonen}

ICD-10-hoveddiagnose ved utskrivning ble funnet for 176 døde og 42 overlevende per 1.2. 2009, i alt 218 (tab 1).

Notat om transfusjon manglet i $59(27 \%)$ av de 218 journalene vi fikk tilgang til (tab 2). Det var signifikant flere med angitt hemoglobinkonsentrasjon før transfusjon blant pasienter med ikke-kirurgiske diagnoser (ICD-10grupper A-C, I-K, N) enn blant pasienter med kirurgiske diagnoser (ICD-10-grupper $\mathrm{M}, \mathrm{O}$, $\mathrm{S}, \mathrm{T}$ ) (khikvadrattest $\mathrm{p}<0,001$ ). 52 pasienter
(24\%) hadde hemoglobinkonsentrasjon før transfusjonen på $\geq 8 \mathrm{~g} / 100 \mathrm{ml}$.

\section{Forbruk av erytrocyttkonsentrater}

Det ble i alt gitt 1162 enheter erytrocyttkonsentrat, fordelt på 471 transfusjonsepisoder. Forbruket utgjorde $8,3 \%$ av årsforbruket ved Ullevål universitetssykehus (upublisert statistikk fra Blodbanken i Oslo). Ingen pasient fikk transfusjon i begge registreringsperioder.

Ved 83 episoder $(18 \%)$ ble det gitt én enhet og ved 290 (62\%) to enheter. Hos 276 av pasientene $(79 \%)$ ble det registrert bare én transfusjonsepisode. Av disse fikk 219 (79\%) én eller to enheter. Maksimalt antall transfusjonsepisoder var ti. Til pasienter som ble retransfundert ble det gitt signifikant flere enheter erytrocyttkonsentrat ved første transfusjonsepisode enn det ble gitt til dem som bare ble registrert med én episode (khikvadrattest for trend $\mathrm{p}<0,001$ ).

Mediant antall transfunderte enheter i registreringsperioden var to (spredning 1-32). Det ble gitt utskiftningstransfusjon til tre nyfødte (én enhet til hver). Massiv transfusjon, definert som ti eller flere enheter i løpet av 24 timer, ble gitt til i alt fem pasienter (1,4\%).

\section{Transfusjon ved kirurgiske inngrep}

Hos 89 (41\%) av de 218 pasientene med tilgjengelige journaldata ble transfusjonen gitt 
Antall blodmottakere

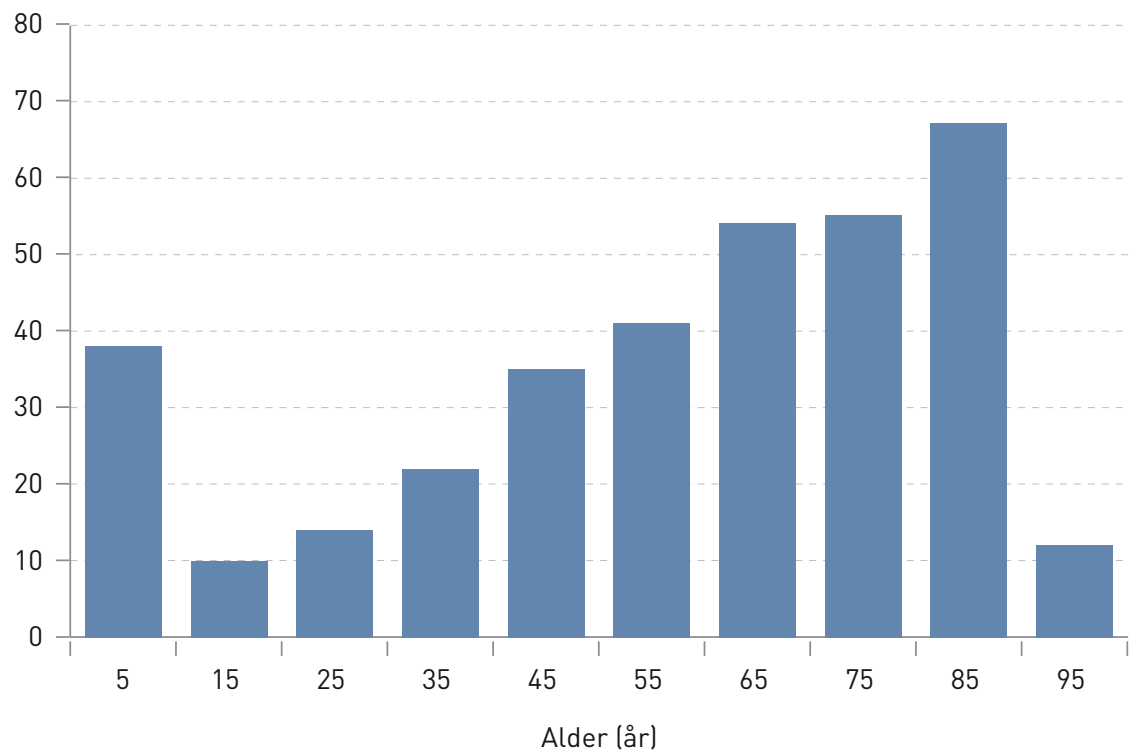

Figur 2 Aldersfordeling hos de 348 pasientene

\section{Andel overlevende (\%)}

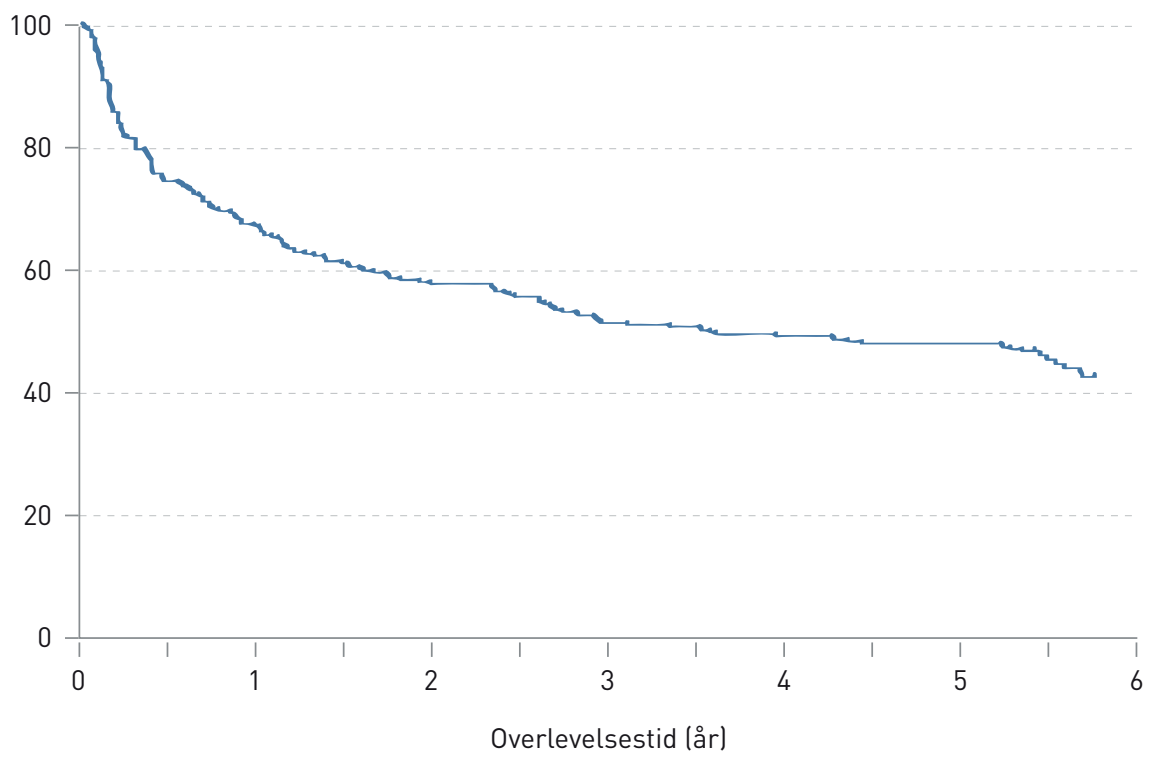

Figur 3 Ikke-justert overlevelseskurve for 330 av de 348 pasientene. Hos 16 pasienter manglet personalia for oppfølging av overlevelse. To pasienter hadde flyttet til utlandet

i tilslutning til et kirurgisk inngrep utført i registreringsperioden. I alt ble det hos disse 89 pasientene ( $26 \%$ av alle i studien) gitt 449 enheter erytrocyttkonsentrat (39\% av alle), fordelt på 157 transfusjonsepisoder $(33 \%$ av alle). Antall transfusjonsepisoder og antall transfunderte enheter var altså noe høyere sett i forhold til pasientantallet for dem med enn for dem uten inngrep, men forskjellene nådde ikke statistisk signifikans (MannWhitneys U-test hhv. $p=0,057$ og $p=0,099$ ).

Tabell 3 viser erytrocyttforbruket ved de forskjellige grupper inngrep. Forbruket var signifikant høyere sett $\mathrm{i}$ forhold til pasientantallet ved inngrep på hjerte og store kar enn ved inngrep på bevegelsesapparatet (Mann-Whitneys U-test $\mathrm{p}<0,05$ ).

\section{Forekomst av blodtypeantistoffer}

I pretransfusjonsprøvene i 2003 ble det påvist irregulære blodtypeantistoffer hos 11 av 348 pasienter $(3,2 \%)$.

Av de 47 overlevende som ga tillatelse til journalinnsyn, avga 38 blodprøve til ny pretransfusjonsprøve. Hos tre av disse var det påvist irregulære antistoffer i 2003, og de samme antistoffene ble påvist i 2008. Blant de øvrige 35 ble anti-Rh(D), anti-Rh(C), anti-Rh(E) og anti-K påvist hos én pasient (immuniseringsfrekvens $=2,6 \%$ ).

\section{Diskusjon}

Alder

Eldre pasienter utgjorde hovedgruppen av transfunderte. Liknende funn er rapportert fra flere vestlige land (10-12, 14-17). Det er da rimelig å anta at eldre dominerer blant transfusjonsmottakere også på landsbasis $\mathrm{i}$ Norge, men dette må bekreftes i mer omfattende studier. Det relativt høye antallet unge pasienter kan til dels skyldes at Ullevål universitetssykehus hadde landets største barneavdeling, med eget senter for kreft hos barn.

\section{Diagnoser}

Mer enn $50 \%$ av pasientene hadde hoveddiagnosen kreft eller andre kroniske lidelser med usikker prognose. Dette er nær det som er rapportert fra andre land $(14,15,18,19)$. Tallet passer også med at ca. $60 \%$ av pasientene fikk transfusjon uten relasjon til kirurgisk inngrep, og at mer enn en tredel av pasientene var døde ett år etter transfusjonen. Man kan derfor anta at mange fikk transfusjon som ledd i palliativ behandling.

I en regional studie fra Frankrike ble det rapportert at nesten $50 \%$ av transfusjonsmottakerne hadde kreftsykdom (11). Fra Nederland er det rapportert at $22 \%$ hadde slik sykdom (19). Våre tall kan være høyere enn det norske landsgjennomsnittet fordi Ullevål universitetssykehus hadde et stort kreftsenter, men det er grunn til å anta at kreftpasienter også utgjør en stor gruppe transfusjonsmottakere, kanskje den største, i vårt land. Det vil ha betydelig interesse å få sikrere kunnskap om dette for å kunne vurdere landets blodbehov $i$ årene som kommer.

I Danmark og Sverige (16) og i Nederland (20) er det vist at mortaliteten hos transfunderte er signifikant høyere enn mortaliteten i den aldersjusterte normalbefolkningen så lenge som 17 år (16) og ti år etter transfusjonen (20). Dette er forenlig med at transfusjon også hos langtidsoverlevende ofte blir gitt til dem med livsforkortende sykdommer. Dette støtter vår tolking. Våre overlevelsesdata ligger nær dem som presenteres av Kamper-Jørgensen og medarbeidere (16) og av Borkent-Raven og medarbeidere (20).

\section{Journalnotater om transfusjon}

Et betydelig antall transfusjoner ble gitt uten at noen begrunnelse ble notert i journalen. Transfusjon skal bare anvendes når annen behandling ikke vil føre til målet, eventuelt innenfor rimelig tid og ressursbruk, det skal ikke være en behandling som brukes regelmessig uten nærmere overveielse (1). Vårt funn kan tyde på at transfusjon ikke sjelden anses som et rutinetiltak som ikke krever journalnotat.

\section{Antall erytrocyttkonsentrater per transfusjonsepisode}

Flertallet av pasientene fikk én eller to enheter erytrocyttkonsentrat, og de fleste ble ikke retransfundert i registreringsperioden. Hos 
en normovolemisk, hemodynamisk stabil person på $70 \mathrm{~kg}$ vil man få $\mathrm{i}$ underkant av $1 \mathrm{~g} / 100 \mathrm{ml}$ økning av Hb-konsentrasjonen per erytrocyttkonsentrat $(1,21)$. Evidensgrunnlaget for erytrocyttransfusjon er generelt utilstrekkelig (22), aller mest i palliativ sammenheng. Det er grunn til å stille spørsmål ved nytten av å heve Hb-konsentrasjonen 1,5-1,8 g, især hos normovolemiske, ikke-blødende pasienter med Hb-konsentrasjon $>8 \mathrm{~g} / 100 \mathrm{ml}$. Pasienter med symptomgivende koronar hjertesykdom utgjør et mulig unntak $(23,24)$. Våre funn kan derfor tale for at flere transfusjonsepisoder med 1-2 enheter kunne vært unngått uten vesentlige problemer for pasienten og at det dermed foreligger et signifikant innsparingspotensial for erytrocyttforbruk. For å få sikrere norske tall for dette bør tilsvarende studier gjøres ved flere sykehus.

Vi fant en tendens til at pasienter som fikk tre eller flere erytrocyttenheter ved første registrerte transfusjonsepisode, ble hyppigere retransfundert enn de som bare fikk 1-2 enheter. Det er rimelig å anta at de førstnevnte oftere ble transfundert som ledd i mer intensiv behandling enn de sistnevnte.

\section{Blodtypeimmunisering}

En prospektiv engelsk undersøkelse viste i 1996 at transfusjon førte til påvisbar blodtypeimmunisering ni måneder etterpå hos ca. $8 \%$ av dem som ble transfundert i tilslutning til elektiv kirurgi (25). Våre tall er for små for videre analyse, og den tilsynelatende lave immuniseringsfrekvensen kan skyldes at noen induserte antistoffer ikke lenger var påvisbare. Det vil være av interesse å undersøke prospektivt om blodtypeimmunsiering forekommer sjeldnere med dagens norske transfusjonspraksis enn det som tidligere er beskrevet fra utlandet.

\section{Studiens begrensninger}

Studien representerer ingen fullstendig beskrivelse av klinisk transfusjonspraksis ved Ullevål universitetssykehus, til det er registreringsperiodene for korte og antallet pasienter for lavt. Spesielt vil vi peke på at et ukjent antall av pasientene kan ha fătt transfusjon eller blitt operert i for- eller etterkant av de to registreringsperiodene. Det mangler også tilgang til kliniske data og inngrepskoder for mer enn tredel, blant andre for samtlige som var under 15 år ved transfusjonstidspunktet. Endelig er det 16 pasienter med ukjent personalia (transfusjon gitt på såkalt nødnummer) det ikke har vært mulig å følge i folkeregisteret. Antall døde kan derfor være større enn det vi har kunnet registrere.

På den annen side omfatter studien 7,6\% av året 2003 og 8,3\% av erytrocyttforbruket ved Ullevål universitetssykehus, og alle transfusjoner i registreringsperioden er inkludert. Vi hadde også tilgang til kliniske data for nesten to tredeler av pasientene $(62,6 \%)$. Vi mener derfor at studien med de angitte forbehold kan beskrives som et

Tabell 1 ICD-10-diagnoser ved utskrivning hos 218 pasienter der journalinnsyn ble mulig

\begin{tabular}{lccc} 
Diagnostisk gruppe (ICD-10-diagnosenummer) & Antall (\%) & Døde & Overlevende \\
\hline Kreft (C00-97) & $76(34,9)$ & 73 & 3 \\
\hline Skader (S00-T98) & $36(16,5)$ & 23 & 13 \\
\hline Hjerte- og karsykdommer (I20-89) & $34(15,6)$ & 27 & 7 \\
Sykdommer i gastrointestinaltractus (K22-93) & $19(8,7)$ & 17 & 2 \\
Anemier (D50-64) & $12(5,5)$ & 11 & 1 \\
\hline Sykdommer i bevegelsesapparatet (M) & $9(4,1)$ & 3 & 6 \\
Obstetriske tilstander (0) & $3(1,4)$ & 0 & 3 \\
Varia & $29(13,3)$ & 22 & 7 \\
Totalt & $218(100)$ & 176 & 42
\end{tabular}

Tabell 2 Journalnotater og deres innhold om indikasjoner i 218 fullstendige journaler

\section{ICD-10-diagnose- Øvrige ICD-10-} gruppe $\mathrm{M}, \mathrm{O}, \mathrm{S}, \mathrm{T}$ diagnosegrupper

\begin{tabular}{lcr} 
Intet notat eller kun nevnt transfusjon ${ }^{1}$ & 24 & 35 \\
$\begin{array}{l}\text { Blødning, nedsatt allmenntilstand, tretthet, volumbehov } \\
\text { eller «lav hemoglobin» }\end{array}$ & 12 & 28 \\
\hline Numeriske pretransfusjonshemoglobinverdier anført ${ }^{2}$ & 13 & 106 \\
\hline Totalt & 49 & 169
\end{tabular}

Herav 46 helt uten notat

${ }^{2}$ Herav 52 med $\mathrm{Hb} \geq 8 \mathrm{~g} / 100 \mathrm{ml}$

Tabell 3 Antall enheter erytrocyttkonsentrat gitt ved ulike typer kirurgiske inngrep

\begin{tabular}{lcccc} 
& Minimum & Median & Maksimum & Antall pasienter \\
\hline Nevrokirurgi & 2 & 3 & 14 & 9 \\
Hjertet og store torakale kar & 1 & 4 & 60 & 16 \\
\hline Andre intervensjoner i thorax & 2 & 5 & 7 & 10 \\
\hline Gastrointestinaltractus & 1 & 2 & 19 & 14 \\
\hline Bevegelsesapparatet & 1 & 2 & 10 & 22 \\
Varia & 1 & 2 & 8 & 18 \\
\hline Totalt & 1 & 3 & 60 & 89
\end{tabular}

«representativt korttidsbilde» av transfusjonsvirksomheten ved Ullevål universitetssykehus i 2003. Ekstrapolering av resultatene til Norge som helhet er forbundet med større usikkerhet, men vår studie er foretatt ved et sykehus som omfatter alle somatiske spesialiteter og har gitt funn som likner på dem som er rapportert internasjonalt. Det er derfor rimelig å anta at funnene ikke representerer noe stort avvik fra forholdene ved norske sykehus i alminnelighet.

\section{Sammenlikning med andre land}

Bare $1,4 \%$ av transfusjonsepisodene omfattet ti eller flere enheter («massiv transfusjon»). Ved Rigshospitalet i København, som har et traumesenter av omtrent samme størrelse som det Ullevål universitetssykehus hadde, var 5,6\% av transfusjonsepisodene i 2009 «massive» (26). Dette kan reflektere en generelt mer restriktiv transfusjonskultur her i landet enn i Danmark, som forbruker $60 \%$ flere erytrocyttkonsentrater per år sett $\mathrm{i}$ forhold til folkemengden enn Norge (3). Det høye forbruket der er neppe positivt for pasientene (27). Samtidig er erytrocyttforbruket i Frankrike ca. 10\% lavere $\mathrm{i}$ forhold til folkemengden enn forbruket i Norge (3). Også i Nederland er det et vesentlig lavere forbruk enn hos oss (3).

Forskjellene mellom landene kan ikke forklares ut fra alders- eller diagnosespektrum hos pasientene, og det er ikke publisert data som tilsier at forskjellene gir målbar effekt på overlevelse eller livskvalitet. Det er da rimelig å anta at Norge har et ikke ubetydelig blodsparingspotensial, til tross for at forbruket hos oss er lavere enn i de øvrige nordiske land (3).

\section{Tiltak for optimalisering av praksis}

Vi har nylig funnet at forbruket av erytrocyttkonsentrater til multitraumepasienter ved Ullevål universitetssykehus ble redusert 
med ca. $25 \%$ fra 2002 til 2007 som konsekvens av bl.a. innføring av strikte transfusjonsprotokoller (28). Reduksjonen hadde ingen innvirkning på hemoglobinkonsentrasjonen hos pasientene. Det er grunn til å anta at innføring av flere slike protokoller vil kunne gi redusert forbruk av erytrocyttkonsentrater også i andre deler av sykehuset. En annen mulighet for å stimulere til sparing kan være at legen som rekvirerer transfusjon, må oppgi diagnose og hemoglobinkonsentrasjon når dette er mulig. I dag formidles ikke slike data til blodbanken.

Journalnotat med angivelse av hemoglobinverdi bør etter vårt syn være et minstekrav som bare fravikes i akuttsituasjoner. Et slikt krav vil trolig virke disiplinerende på indikasjonsstillingen og bidra til å begrense forbruket.

Fra 2000 til 2008 økte Norges forbruk av erytrocyttkonsentrater med ca. $14 \%$ (3). I årene som kommer, vil det bli flere eldre (29). Man vil da kunne forvente en fortsatt økning i forbruket. Imidlertid har det norske forbruket stagnert etter 2008 (3). I Nederland har forbruket av erytrocyttkonsentrater gått ned med nesten $20 \%$ siden 1998, til tross for at det $\mathrm{i}$ utgangspunktet var vesentlig lavere enn det norske $(3,30)$. Det virker rimelig å anta at endringene reflekterer en tendens til en mer restriktiv transfusjonspraksis i begge land $(2,30,31)$.

\section{Konklusjon}

Erytrocyttransfusjon blir mest gitt til eldre pasienter med kroniske sykdommer med usikker eller dårlig prognose, særlig kreft. Dette er samme forbruksmønster som rapporteres fra andre vestlige land. Forbruket er generelt høyest hos pasienter som gjennomgår kirurgiske inngrep. Den kliniske dokumentasjonen er ikke sjelden mangelfull. Indikasjonsstillingen synes $i$ en del tilfeller å være basert på rutiner og i for liten grad på vitenskapelig evidens og patofysiologisk forståelse.

$\mathrm{Vi}$ antar at det i Norge som helhet er et liknende forbruksmønster og at det er et innsparingspotensial når det gjelder bruk av erytrocyttkonsentrater. Nye data kan tyde på at forbruket på landsbasis stagnerer og at situasjonen dermed er i bedring. Erytrocyttransfusjon fører som regel ikke til blodtypeimmunisering.

\section{Hans Erik Heier (f. 1944)}

er professor emeritus ved Institutt for klinisk medisin, Universitetet i Oslo. Han var tidligere avdelingsoverlege ved Avdeling for immunologi og transfusjonsmedisin, Ullevål universitetssykehus.

Forfatter har fylt ut ICMJE-skjemaet og oppgir ingen interessekonflikter.

\section{Ivo Nentwich (f. 1961)}

er overlege ved Avdeling for immunologi og transfusjonsmedisin

Forfatter har fylt ut ICMJE-skjemaet og oppgir ingen interessekonflikter.

\section{Liv Jorunn Garvik (f. 1959)}

er bioingeniør II ved Avdeling for immunologi og transfusjonsmedisin.

Forfatter har fylt ut ICMJE-skjemaet og oppgir ingen interessekonflikter.

\section{Berit Gran (f. 1952)}

er avdelingsleder/bioingeniør ved Avdeling for immunologi og transfusjonsmedisin.

Forfatter har fylt ut ICMJE-skjemaet og oppgir ingen interessekonflikter.

\section{Litteratur}

1. Håndbok i transfusjonsmedisin. www helsedirektoratet no/publikasjoner/ rapporter/h_ndbok_i_transfusjonsmedisin_367814 (27.12.2011).

2. Engoren M. Transfusion: is merely not bad good enough? Acta Anaesthesiol Scand 2011: 55: 907-9.

3. Flesland $\varnothing$. Sjøberg JJ. Blodtransfusjonstjenesten i Norge: statistikk for 2010 (Norwegian Transfusion Statistics 2010) www. hemovigilans.no/Dokumenter (27.12.2011)

4. Heier HE. Produksjon og forbruk av blodprodukter i Norge. Tidsskr Nor Lægeforen 1993; 113: 18-22.

5. Sirchia G, Giovanetti AM, McClelland DBL et al. Safe and good use of blood in surgery. Use of blood products and artificial colloids in 43 European communities. Luxembourg: Office for Official Publications of the European Communities, 1994.

6. Hasley PB, Lave JR, Hanusa BH et al. Variation in the use of red blood cell transfusions. A study of four common medical and surgical conditions. Med Care 1995; 33: 1145-60.

7. Goodnough LT, Johnston MF, Toy PT. The variability of transfusion practice in coronary artery bypass surgery. JAMA 1991; 265: 86-90.

8. Friedman MT. Blood transfusion practices: a little consistency please. Blood Transfus 2011; 9: 362-5.

9. Liumbruno GM, Rafanelli D. Appropriateness of blood transfusion and physicians' education: a continuous challenge for Hospital Transfusion Committees? Blood Transfus 2012; 10: 1-3.

10. Vamvakas EC, Taswell HF. Epidemiology of blood transfusion. Transfusion 1994; 34: 464-70.

11. Mathoulin-Pélissier S, Salmi LR, Verret C et al.
Blood transfusion in a random sample of hospitals in France. Transfusion 2000; 40: 1140-6.

12. Wells AW, Mounter PJ, Chapman CE et al. Where does blood go? Prospective observational study of red cell transfusion in north England. BMJ 2002; 325: $803-6$

13. Heier HE, Hervig T. Mot permanent blodkrise i Norge? Dagens Medisin 10.10.2010.

14. Titlestad K. Clinical epidemiology of transfusion medicine. Transfus Apheresis Sci 2005. 32: 3-5.

15. Cobain TJ, Vamvakas EC, Wells A et al. A survey of the demographics of blood use. Transfus Med 2007; 17: 1-15

16. Kamper-Jørgensen M, Ahlgren M, Rostgaard K et al. Survival after blood transfusion. Transfusion 2008; 48: 2577-84.

17. Ali A, Auvinen MK, Rautonen J. The aging population poses a global challenge for blood services. Transfusion 2010: 50: 584-8.

18. Madsen JT, Kimper-Karl ML, Sprogøe U et al. One-year period prevalence of blood transfusion. Transfus Med 2010; 20: 191-5.

19. Borkent-Raven BA, Janssen MP, van der Poel CL et al. The PROTON study: profiles of blood product transfusion recipients in the Netherlands. Vox Sang 2010; 99: 54-64

20. Borkent-Raven BA, Janssen MP, van der Poel CL et al. Survival after transfusion in the Netherlands. Vox Sang 2011; 100: 196-203.

21. Klein HG. Anstee DJ. Mollison's Blood transfusion in clinical medicine. 11. utg. Oxford: Blackwell, 2005: 383.

22. Heier HE, Bugge W, Hjelmeland K et al. Transfusion vs. alternative treatment modalities in acute bleeding: a systematic review. Acta Anaesthesiol Scand 2006; 50: 920-31.

23. Carson JL, Hill S, Carless P et al. Transfusion triggers: a systematic review of the literature. Transfus Med Rev 2002; 16: 187-99.

24. Klein HG, Anstee DJ. Mollison's Blood transfusion in clinical medicine. 11. utg. Oxford: Blackwell, 2005: $386-7$

25. Redman M, Regan F, Contreras M. A prospective study of the incidence of red cell allo-immunisation following transfusion. Vox Sang 1996; 71: 216-20.

26. Johansson PI, Stensballe J. Effect of Haemostatic Control Resuscitation on mortality in massively bleeding patients: a before and after study. Vox Sang 2009; 96: 111-8

27. Johansson PI, Titlestad K, Møller BK et al. Overtransfusion - en dansk uvane med alvorlige konsekvenser. Ugeskr Læger 2009; 171: 1072.

28. Nakstad AR, Skaga NO, Pillgram-Larsen J et al. Trends in transfusion of trauma victims - evalu ation of changes in clinical practice. Scand J Trauma Resusc Emerg Med 2011: 19: 23.

29. Brunborg H, Texmon I. Befolkningsframskrivninger 2010-2060. Økonomiske Analyser 2010; nr. 4 : 28-39.

30. Borkent-Raven BA, Janssen MP, Van Der Poel CL. Demographic changes and predicting blood supply and demand in the Netherlands. Transfusion 2010 50: $2455-60$

31. Reine PA, Kongsgaard UE, Smith-Erichsen N. Hemoglobingrenser og transfusjonspraksis blant norske anestesiologer. Tidsskr Nor Lægeforen 2004; 124: 2610-2.

Mottatt 1.6. 2011, første revisjon innsendt 20.11 2011, godkjent 31.5. 2012. Medisinsk redaktør Are Brean. 